\title{
Dano causado por Bipolaris maydis em Panicum maximum cv. Tanzânia
}

\author{
Damages caused by Bipolaris maydis in \\ Panicum maximum cv. Tanzânia
}

Alexandra da Silva Martinez ${ }^{1}$; Gilmar Franzener²; José Renato Stangarlin ${ }^{3 *}$

\section{Resumo}

O objetivo deste trabalho foi avaliar o dano causado por Bipolaris maydis (helmintosporiose) na quantidade e qualidade da produção do capim Tanzânia. Plantas de capim Tanzânia foram cultivadas em vasos de tubos de PVC (50 cm de altura x $15 \mathrm{~cm}$ de diâmetro) contendo mistura solo/areia (3:1). As plantas foram inoculadas com suspensões de esporos do patógeno com diferentes concentrações $\left(10^{2}\right.$, $10^{4}$ e $10^{6}$ conídios $/ \mathrm{mL}$ ), visando obter gradiente de severidade de manchas foliares. Foram realizadas avaliações semanais da severidade e do número de perfilhos. Após quatro semanas avaliou-se o peso da matéria fresca de folhas (MF), porcentagem de matéria seca (PMS), de proteína bruta (PB), de fibra em detergente neutro (FDN) e de fibra em detergente ácido (FDA). A doença reduziu significativamente o perfilhamento e MF a partir da segunda avaliação $(P<0,05)$. Não houve correlação significativa entre as variáveis PMS, FDA e área abaixo da curva de progresso da doença (AACPD). No entanto, houve correlação positiva $(\mathrm{P}<0,01)$ e negativa $(\mathrm{P}<0,05)$ entre $\mathrm{PB}$ e FDN, respectivamente, com a AACPD, como possível resultado da atividade do patógeno. Estes resultados indicam que B. maydis inibe o desenvolvimento do capim Tanzânia e promove alteração na qualidade da forragem.

Palavras-chave: Mancha foliar, helmintosporiose, função de dano

\begin{abstract}
The aim of this research was to evaluate the damage caused by Bipolaris maydis in the quantity and quality of the Tanzania grass production. Tanzania grass plants were cultivated in pots of PVC tubes (50 $\mathrm{cm}$ of height $\mathrm{x} 15 \mathrm{~cm}$ of diameter) containing a mixture of soil and sand (3:1). The plants were inoculated with spore pathogen suspension containing $10^{2}, 10^{4}$ and $10^{6}$ conidia $/ \mathrm{mL}$ to obtain different levels of disease. Severity and number of tillers were evaluated weekly. After four weeks, it were evaluated the weight of the fresh matter of leaves (FM), percentage of dry matter (DM), crude protein (CP), neutral detergent fiber (NDF) and acid detergent fiber (ADF). The disease reduced significantly the plant tillering and FM after the second evaluation $(\mathrm{P}<0.05)$. There was no significant correlation among the variables DM, ADF, and the area under disease progress curve (AUDPC). However, there were positive $(\mathrm{P}<0.01)$ and negative $(\mathrm{P}<0.05)$ correlations among $\mathrm{CP}$ and NDF, respectively, with AUDPC, as possible result of the activity of the pathogen. These results showed that $B$. maydis inhibits the development of the Tanzania grass and promotes alteration in the quality of the forage.
\end{abstract}

Key words: Leaf spot, helminthosporium disease, damage equation

\footnotetext{
${ }^{1}$ Zootecnista, Mestre - Universidade Estadual do Oeste do Paraná, UNIOESTE. Cx. P. 91 - 85960-000 - Marechal Cândido Rondon, PR. E-mail: alefranzener@yahoo.com.br

${ }^{2}$ Engenheiro Agrônomo, Mestre - Universidade Estadual do Oeste do Paraná, UNIOESTE. Cx. P. 91 - 85960-000 - Marechal Cândido Rondon, PR. E-mail: gfranzener@hotmail.com

${ }^{3}$ Engenheiro Agrônomo, Doutor, Professor Associado, Bolsista do CNPq - Universidade Estadual do Oeste do Paraná, UNIOESTE. Cx. P. 91 - 85960-000 - Marechal Cândido Rondon, PR. E-mail: jrstangarlin@pq.cnpq.br

* Autor para correspondência
} 


\section{Introdução}

A gramínea forrageira Panicum maximum Jacq. cv. Tanzânia-1 vem ganhando destaque na produção pecuária no país e no estado do Paraná, por sua maior facilidade de manejo, pois suas folhas são mais estreitas, decumbentes e sem pilosidade, o que aumenta a aceitabilidade pelos animais. Esta variedade é muito utilizada para pastejo no sistema rotacionado, pois devido à elevação rápida do meristema apical se torna bastante vulnerável à eliminação pelo pastejo em sistema contínuo (SANTOS, 2002).

A produção de matéria seca (MS) é um fator limitante para se obter boa exploração pecuária. Esta produção pode ser influenciada por inúmeros fatores como condições edáficas, climáticas, manejo e ataque de pragas e doenças (SANTOS, 2002). O impacto de doenças ainda é pouco estudado em $P$. maximum. Outro componente de produção importante é o número de perfilhos, pois proporciona à planta manter um conjunto de lâminas foliares que permite ter produção de fotoassimilados para manutenção, crescimento e reserva (BRISKE, 1996).

A qualidade nutricional de uma forrageira é representada principalmente pela associação de sua composição bromatológica, digestibilidade e consumo voluntário (GERDES et al., 2000). Por isso, é de importância o conhecimento dos teores de proteína bruta (PB), fibra em detergente neutro (FDN, fração composta por celulose, hemicelulose, lignina e proteínas lignificadas), fibra em detergente ácido (FDA, fração composta quase que exclusivamente de lignina e celulose), teor de matéria seca e digestibilidade da matéria seca (CANO et al., 2004).

Lam (1985) e Isawa (1983) relatam que, após infecções causadas por fungos fitopatogênicos, algumas gramíneas e leguminosas forrageiras apresentam alterações bioquímicas que levam à perda da qualidade nutricional, bem como alterações em sua palatabilidade para os animais devido à redução na concentração de proteínas, aminoácidos, açúcares, carboidratos solúveis e na digestibilidade da matéria seca, além do aumento de compostos fenólicos e lignina nas plantas infectadas.

A lignina, juntamente com a celulose e outros polissacarídeos que ocorrem na parede celular das plantas superiores, funciona como uma barreira física à penetração fúngica. Porém, segundo Rego et al. (2003), quanto mais lignificada a parede celular, maior o teor de FDN e menor o teor de proteína, dificultando a digestibilidade da forragem, o que provoca menor aceitação por parte dos animais.

Manchas foliares causadas por uma grande variedade de espécies de fungos fitopatogênicos são as principais doenças encontradas em gramíneas forrageiras (LENNÉ, 1994). Uma vez estabelecida a doença, o patógeno passa a avançar em direção ao interior do tecido do hospedeiro e a comprometer a integridade do mesmo em todos os níveis (LEITE; PASCHOLATI, 1995). Os microrganismos podem comprometer o desenvolvimento das plantas com conseqüente interferência na alimentação dos animais, devido à redução na quantidade ofertada (RUSSOMANNO, 1998).

Bipolaris maydis (Nisik e Miyake) Shoemaker é um fungo que já foi relatado em muitas espécies vegetais, entre estas causando a helmintosporiose do milho, doença conhecida há muitos anos no Brasil e que provoca grandes prejuízos. Em 2003 este patógeno foi relatado pela primeira vez em capim Tanzânia no Brasil causando mancha foliar (CHARCHAR et al., 2003). Embora seu relato seja recente, Martinez (2004), realizando levantamento de doenças em gramíneas forrageiras em Marechal Cândido Rondon/PR, encontrou manchas foliares causadas por $B$. maydis com grande incidência em cultivares de $P$. maximum, sobretudo na cultivar Tanzânia-1. Os sintomas caracterizam-se por inúmeras lesões nas folhas de tamanhos e formatos variáveis, geralmente em torno de 0,3-1,0 cm. Em ataques severos, as lesões coalescem em largas áreas escuras e necróticas afetando toda a parte aérea da planta. No entanto, ainda não há informações em 
relação aos danos causados por esta doença em capim Tanzânia.

Diante do exposto, este trabalho teve por objetivo avaliar o dano na quantidade e qualidade de matéria seca produzida pela gramínea forrageira Panicum maximum cv. Tanzânia-1 infectada por B. maydis.

\section{Material e Métodos}

As análises laboratoriais foram realizadas nos Laboratórios de Fitopatologia e de Nutrição Animal da Universidade Estadual do Oeste do Paraná UNIOESTE, em Marechal Cândido Rondon/PR. Os ensaios de campo foram conduzidos em casa de vegetação do Núcleo de Estações Experimentais da mesma instituição.

Sementes de $P$. maximum cv. Tanzânia-1 foram depositadas em vasos de tubos de PVC com perfurações laterais $(15 \mathrm{~cm}$ de diâmetro/50 $\mathrm{cm}$ de altura) dispostos verticalmente, contendo mistura de solo/areia na proporção de 3:1.

O fungo B. maydis foi isolado em meio BDA (batata-dextrose-ágar) de plantas sintomáticas de capim Tanzânia cultivadas no município de Marechal Cândido Rondon/PR. A confirmação da espécie foi realizada com auxílio da chave de identificação de Muchovej, Muchovej e Ribeiro-Nesio (1988) e da descrição de Charchar et al. (2003). O meio de cultura utilizado para crescimento e manutenção do isolado foi o meio BDA. Para confirmação da patogenicidade do isolado, este foi inoculado em plantas de capim Tanzânia por meio de suspensão aquosa ( 1 x $10^{4}$ conídios $\left./ \mathrm{mL}\right)$ e após reproduzir os sintomas foi novamente isolado em meio BDA.

Para o preparo de inóculo foram utilizadas colônias jovens crescidas em meio BDA durante 15 dias a temperatura de $25{ }^{\circ} \mathrm{C}$. Foram obtidas suspensões em água com diferentes concentrações de conídios $\left(10^{2}, 10^{4}\right.$ e $10^{6}$ conídios $\left./ \mathrm{mL}\right)$ do patógeno, visando obter gradiente de severidade da doença.

Asinoculações foramrealizadas compulverizador manual quando as plantas atingiram 20 e $35 \mathrm{~cm}$ de comprimento de lâmina foliar (duas inoculações espaçadas de 14 dias). Após a pulverização até ponto de escorrimento, as plantas foram cobertas com sacos plásticos e mantidas em câmara úmida por $20 \mathrm{~h}$.

Para estabelecer um gradiente de severidade, foram utilizadas três concentrações de esporos de $B$. maydis $\left(10^{2}, 10^{4}\right.$ e $10^{6}$ conídios $\left./ \mathrm{mL}\right)$, tendo como testemunha plantas não inoculadas (apenas pulverizadas com água). Cada concentração teve sete repetições dispostas em delineamento inteiramente casualizado sendo cada uma composta por uma planta, utilizando-se para tanto o método da planta individual para obtenção dos dados para estimar danos (BERGAMIN FILHO, 1995).

A quantificação dos sintomas causados por $B$. maydis foi feita com escala diagramática previamente elaborada para este estudo (não publicada) com seis níveis de severidade: 0,$4 ; 1 ; 3 ; 6 ; 13$ e $26 \%$. A severidade da doença foi estimada em porcentagem em 10 folhas representativas de cada planta. As avaliações da severidade e a contagem do número de perfilhos por planta foram realizadas com intervalos de sete dias, iniciando assim que apareceram os primeiros sintomas até que as plantas atingiram 70 $\mathrm{cm}$ de comprimento de lâmina foliar.

Com os dados de severidade ao longo do tempo, foi calculada a área abaixo da curva de progresso da doença (AACPD) (SHANNER; FINNEY, 1977):

$$
\mathrm{AACPD}=\sum_{\mathrm{i}}^{\mathrm{n}-1}\left[\left(\mathrm{x}_{\mathrm{i}}+\mathrm{x}_{\mathrm{i}+1}\right) \times 0,5\right] \times\left[\mathrm{t}_{\mathrm{i}+1}-\mathrm{t}_{\mathrm{i}}\right]
$$

onde, $n$ é o número de avaliações, $x$ é a severidade de doença e $\left[t_{i+1}-t_{i}\right]$ é o intervalo de avaliações consecutivas.

Quando as plantas atingiram $70 \mathrm{~cm}$ de comprimento de lâmina foliar, foram extraídas e pesadas as folhas de cada planta individualmente para obtenção da matéria fresca (MF). Em seguida, as folhas foram colocadas em sacos de papel e levadas para secagem em estufa a $60{ }^{\circ} \mathrm{C}$ por quatro dias quando foram pesadas novamente para obtenção da matéria seca (MS). A partir destes dados calculou-se a porcentagem de matéria seca (PMS) pela fórmula: 
$\mathrm{PMS}=\mathrm{MS} / \mathrm{MFx} 100$. O número de perfilhos foi estimado visualmente.

Para avaliar a qualidadenutricionalde $P$. maximum foram realizadas análises para a determinação da proteína bruta $(\mathrm{PB})$, fibra em detergente neutro (FDN) e fibra em detergente ácido (FDA), segundo a metodologia proposta por Silva (1998).

Os dados foram analisados por equações de regressão entre as variáveis quantidade de doença, produção e qualidade da forragem, utilizando-se o programa Sigma Plot 2000. Os valores de severidade foram transformados em arcosen raiz de $\mathrm{x} / 100$ para análise estatística.

\section{Resultados e Discussão}

Sítios de infecção puderam ser observados $20 \mathrm{~h}$ após a inoculação com B. maydis, indicando a alta

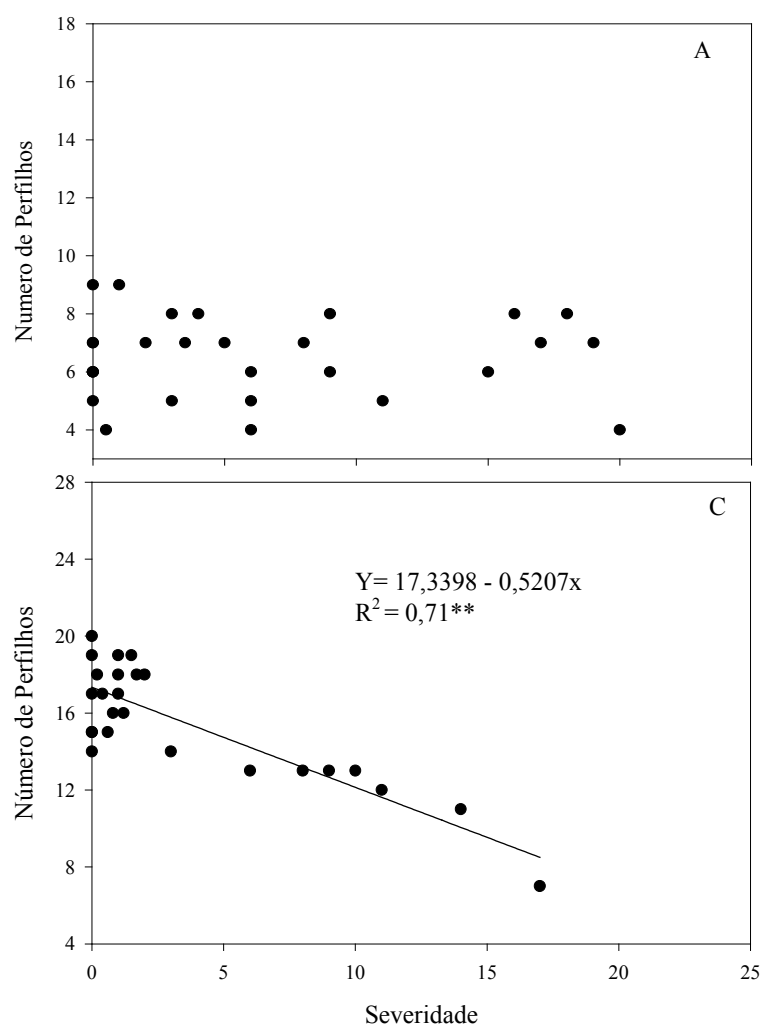

agressividade desse isolado. Estes resultados foram observados em ambas as inoculações realizadas. Com a utilização de diferentes concentrações de inóculo observaram-se também, diferentes níveis de severidade da doença nas plantas que variaram de 0 a $20 \%$.

\section{Componentes de produção}

Número de perfilhos

Na primeira avaliação, realizada um dia após a inoculação, não houve correlação entre a severidade da doença e o número de perfilhos (Figura 1). Porém, já na segunda e igualmente nas avaliações seguintes, houve correlação entre essas variáveis. Assim, a ocorrência da doença durante o desenvolvimento das plantas afetou negativamente, de forma linear, a emissão de perfilhos.

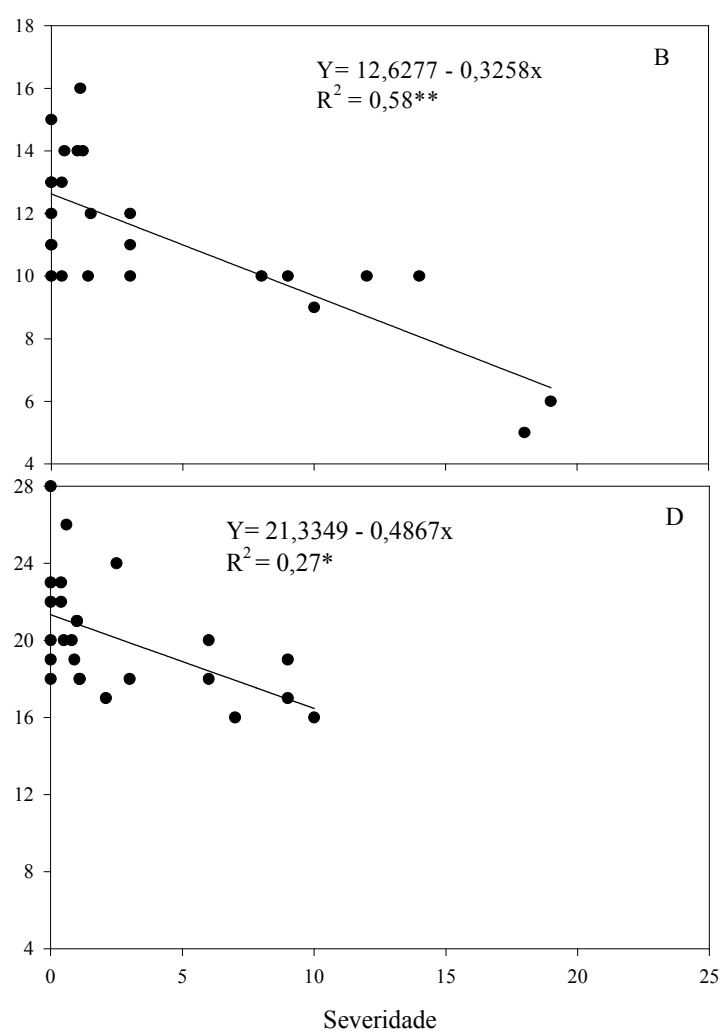

Figura 1. Relação entre número de perfilhos de capim Tanzânia e severidade da mancha foliar de B. maydis. (A), (B), (C) e (D): avaliações realizadas aos 1, 8, 15 e 22 dias após a inoculação, respectivamente. Asteriscos indicam significância a $\mathrm{P}<0,01(* *)$ e a $\mathrm{P}<0,05(*)$. 
A obtenção de significativa relação linear com coeficientes de determinação $\left(\mathrm{R}^{2}\right)$ relativamente baixos (abaixo de 0,70) é comum em ensaios dessa natureza (DALLAGNOL et al., 2006; GODOY; CANTERI, 2004). Os baixos coeficientes de determinação obtidos nesse tipo de experimento devem-se principalmente à variação natural de produção que existe entre plantas individuais, mesmo que geneticamente idênticas, devido, sobretudo, a condições de ambiente (BERGAMIN FILHO, 1995).

Segundo Teixeira et al. (2005), na fase de desenvolvimento vegetativo, os principais drenos de fotoassimilados em $P$. maximum são: perfilhos, raízes, folhas adultas e meristema terminal, ocorrendo, portanto, diferença na distribuição de fotoassimilados das plantas em função do nível de inserção das folhas. Durante o estágio vegetativo, as folhas do topo exportam mais fotoassimilados para o meristema apical, enquanto as folhas da base exportam para as raízes e perfilhos. Como a severidade da doença foi maior nas folhas da base, pois não houve condições ambientais para a infecção natural das folhas que se desenvolveram posteriormente, ou seja, ocorreu apenas monociclo, a distribuição de fotoassimilados para a formação dos perfilhos foi prejudicada, acarretando na redução do número de perfilhos por planta.

Peso da matéria fresca e porcentagem de matéria seca

Os resultados de peso da matéria fresca (MF) e porcentagem de matéria seca são apresentados na Figura 2. Os valores de MF variam de 5,75 a 32,33 gramas $(\mathrm{P}<0,05)$, e para a porcentagem de matéria seca (PMS) os resultados variam de 21,3 a 24,9\%.

Observa-se que houve correlação significativa $(\mathrm{P}<0,05)$ entre AACPD e a MF (Figura 2), indicando que a doença reduziu a MF das plantas de capim Tanzânia. Portanto, com esses dados, aliados aos valores de número de perfilhos, pode-se afirmar que $B$. maydis é capaz de afetar negativamente, e de forma linear, o desenvolvimento de capim Tanzânia. Não houve correlação entre PMS e AACPD.
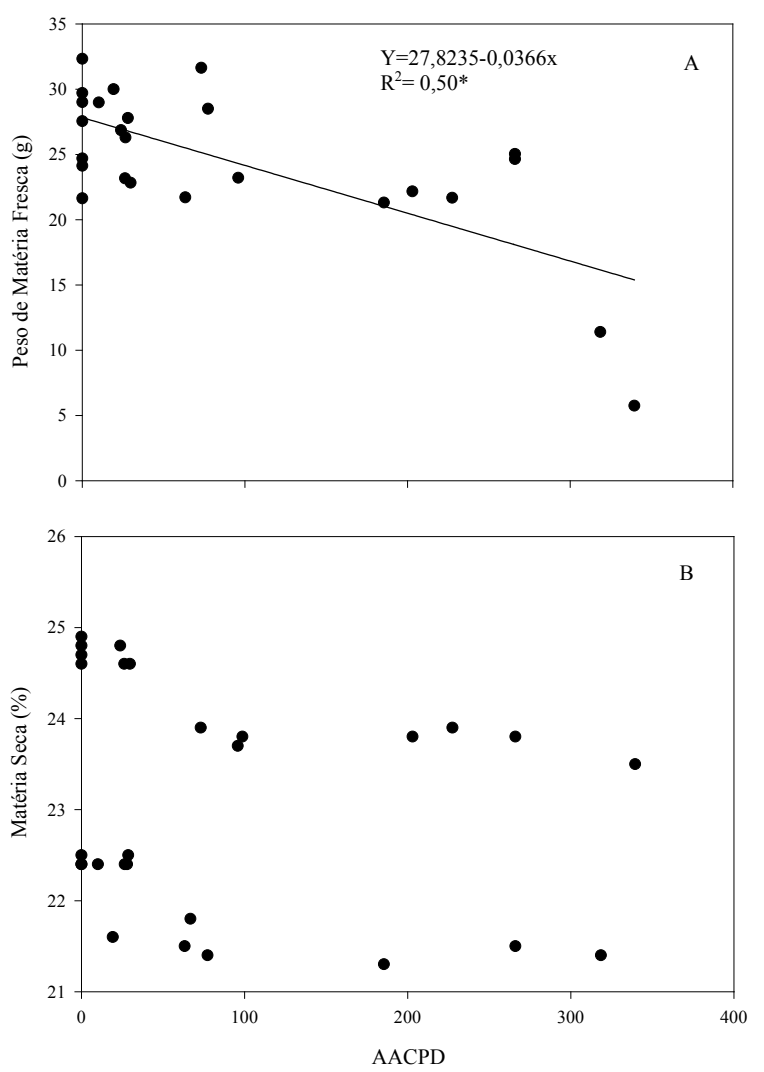

Figura 2. Relação entre peso de matéria fresca (g) (A) e porcentagem de matéria seca (\%) (B) com a área abaixo da curva de progresso da doença (AACPD) em plantas de capim Tanzânia inoculadas com B. maydis. Asterisco indica significância a $\mathrm{P}<0,05$ (*).

Anjos et al. (2004), relatando a ocorrência de B. maydis causando mancha foliar na gramínea forrageira Paspalum atratum cv. Pojuca no Brasil, citam que as lesões necróticas nas folhas causaram danos consideráveis, com redução da área fotossintética e perdas de produção de massa verde e de sementes.

Embora a alteração no desenvolvimento e o surgimento de lesões necróticas pudessem, naturalmente, influenciar na porcentagem de matéria seca, esta característica está mais intimamente relacionada ao estádio de desenvolvimento da planta (TEODORO; AQUINO; CHAGAS, 2002), justificando os resultados obtidos. 


\section{Qualidade nutricional}

\section{Proteina bruta (PB)}

Os valores de $\mathrm{PB}$ variaram de 6,8 a 17,2\% (Figura 3). Observa-se que houve correlação entre os valores de PB e AACPD, indicando que a ocorrência da doença acarretou em incremento significativo $(\mathrm{P}<0,01)$ no conteúdo de $\mathrm{PB}$ nas folhas de capim Tanzânia.

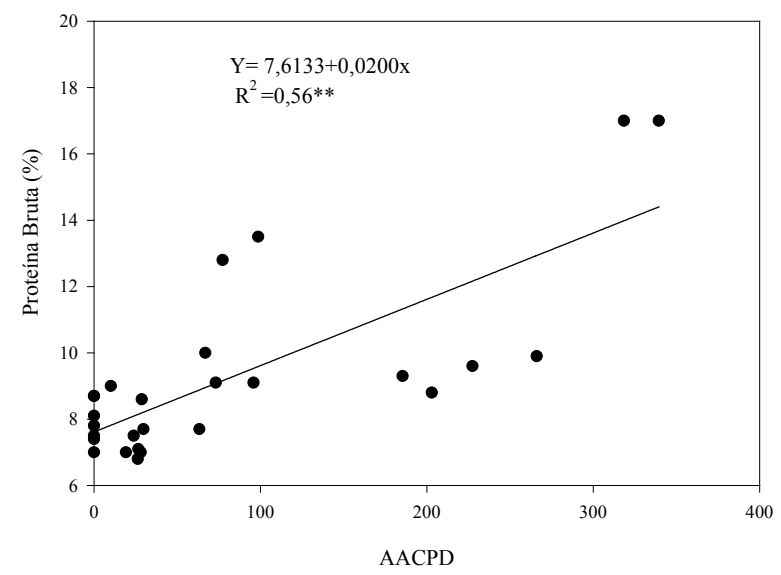

Figura 3. Relação entre porcentagem de proteína bruta e área abaixo da curva de progresso da doença (AACPD) em plantas de capim Tanzânia inoculadas com B. maydis. Asteriscos indicam significância a $\mathrm{P}<0,01(* *)$.

Leite e Pascholati (1995) afirmam que pode haver aumento considerável na síntese de proteína em tecidos infectados devido a processos metabólicos de produção de compostos estruturais e bioquímicos para defesa das células hospedeiras ao agente infeccioso, o que pode ocorrer tanto em materiais resistentes quanto suscetíveis. Segundo Goodman, Királi e Wood (1986), o aumento no teor de N total pode ser atribuído em parte à síntese pelo patógeno, resultando no aumento de ácidos nucléicos (RNA), proteínas usadas para o crescimento de hifas e produção de esporos. Por outro lado, Isawa (1983) encontrou decréscimo de $40 \%$ no teor de nitrogênio (N) em folhas de Lolium multiflorum infectadas por Dreschlera festucae. Segundo Lam (1985) este decréscimo pode ocorrer em função de variações na idade, estado nutricional do hospedeiro e estágio de desenvolvimento da doença, e pode variar de um hospedeiro para outro. Em estágios mais antecipados da doença, o teor de $\mathrm{N}$ total do complexo patógenohospedeiro pode aumentar, mas, em estágios mais tardios ocorre decréscimo devido à decomposição de proteínas em função da quebra da estrutura celular ou pelo fato de alguns patógenos utilizarem o $\mathrm{N}$ da planta para a síntese de seus aminoácidos, proteínas e ácidos nucléicos (LYTTLETON, 1973).

Segundo Gerdes et al. (2000), teores de PB inferiores a $7 \%$ na matéria seca de gramíneas tropicais promovem redução na digestão dos mesmos devido ao inadequado nível de nitrogênio para os microrganismos do rumem.

\section{FDN e FDA}

Os valores de FDN variaram de 61,5 a 74\%, enquanto os valores de FDA variaram de 24,9 a $31,6 \%$. Observa-se que apenas houve correlação significativa $(\mathrm{P}<0,05)$ com a AACPD para FDN (Figura 4).

Durante a penetração e colonização, os fitopatógenos atravessam repetidamente as paredes celulares dos hospedeiros. A maioria dos fitopatógenos pode produzir uma variedade de enzimas, normalmente extracelulares, que atuam na degradação dos componentes da parede celular como celulose, hemicelulose e lignina (LEITE; PASCHOLATI, 1995).

Se comparados os valores de FDN com PB, estes resultados são pertinentes com os obtidos por Rego et al. (2003), que encontraram correlação negativa entre os teores de FDN e PB e com digestibilidade, indicando que à medida que aumentou o conteúdo da parede celular, houve redução do teor de PB e, conseqüentemente, também da digestibilidade.

Segundo Lam (1985) e Isawa (1983), pode haver decréscimo na digestibilidade de plantas forrageiras da ordem de duas a quatro unidades em função da redução de carboidratos solúveis e aumento dos conteúdos de parede celular, o que pode ser 
considerado de importância prática, pois afeta a palatabilidade e a digestibilidade das forragens.

Quanto aos resultados de FDA observou-se ausência de correlação com AACPD. Portanto, a ocorrência de doença não afetou significativamente (P > 0,05) o teor de FDA das plantas de capim Tanzânia. Assim, talvez a infecção fúngica tenha exercido efeito maior sobre outros componentes da parede celular, com menor atividade sobre lignina e celulose, principais representantes da FDA.

Os valores de FDA acima de 35 a 40\% podem prejudicar a digestibilidade das gramíneas tropicais (REGO et al., 2003). Valores crescentes de FDA evidenciam o envelhecimento da forragem e acréscimo de componentes de parede celular (CANO et al., 2004).

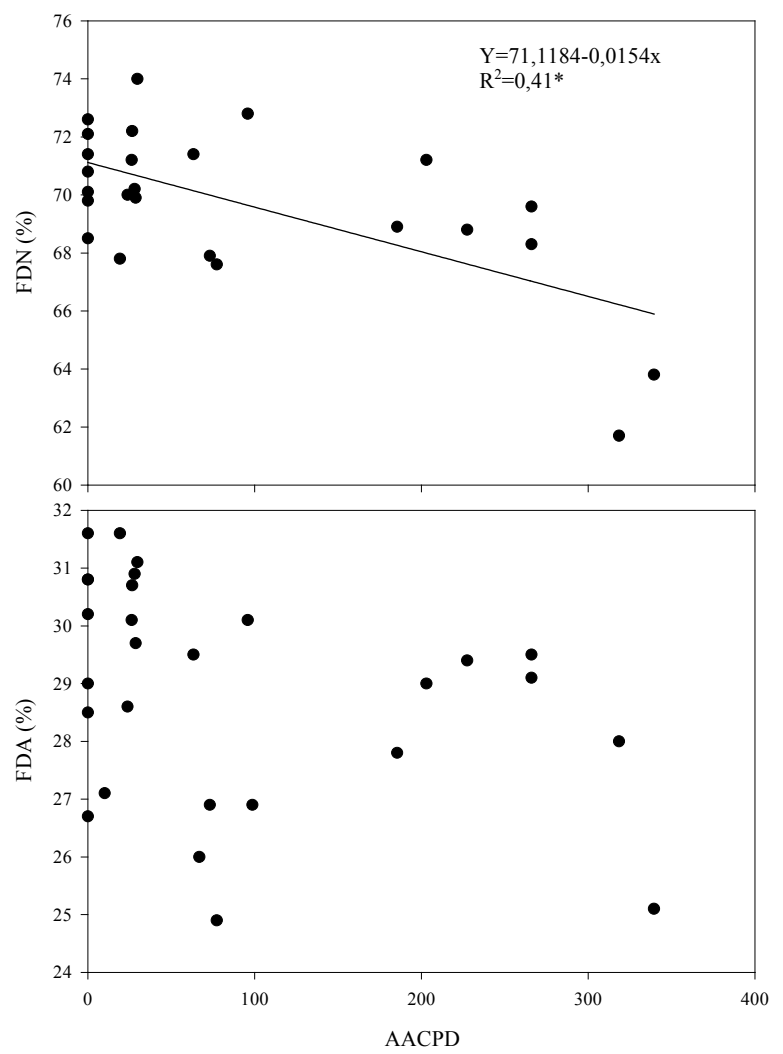

Figura 4. Relação entre porcentagem de fibra em detergente neutro (FDN) e fibra em detergente ácido (FDA) com a área abaixo da curva de progresso da doença (AACPD) em plantas de capim Tanzânia inoculadas com B. maydis. Asteriscos indicam significância a $\mathrm{P}<0,05(*)$.

\section{Conclusões}

A mancha foliar causada por B. maydis afeta o desenvolvimento e a produção do capim - Tanzânia, inibindo significativamente a formação de perfilhos e o peso da matéria fresca, sem alterar, no entanto, a porcentagem de matéria seca. Além disso, a doença promove alteração em aspectos relacionados à qualidade da forragem, com redução de FDN (componentes da parede celular) e incremento no teor de proteína bruta.

\section{Referências}

ANJOS, J. R. N.; CHARCHAR, M. J. A.; TEIXEIRA, R. N.; ANJOS, S. N. Ocorrência de Bipolaris maydis causando mancha foliar em Paspalum atratum cv. pojuca no Brasil. Fitopatologia Brasileira, Brasília, v. 29, n. 6, p. 656-658, 2004.

BERGAMIN FILHO, A. Avaliação de danos e perdas. In: BERGAMIN FILHO, A.; KIMATI, H.; AMORIM, L. (Ed.). Manual de fitopatologia: princípios e conceitos. São Paulo: Ceres, 1995. v. 1, cap. 33, p. 672-690.

BRISKE, D. D. Strategies of plant survival in grazing systems: a functional interpretation. In: HODGSON, J.; ILLIUS, A. W. (Ed.). The Ecology and management of grazing systems. Wallingford: CAB International, 1996. cap. 2, p. 37-68.

CANO, C. C. P.; CECATO, U.; CANO, M. W.; SANTOS, G. T.; GALBEIRO, S.; MARTINS, E. N.; MIRA, R. T. Valor nutritivo do Capim-Tanzânia (Panicum maximum Jacq. cv. Tanzânia-1) pastejado em diferentes alturas. Revista Brasileira de Zootecnia, Viçosa, MG, v. 33, n. 3, p. 1959-1968, 2004. Suplemento.

CHARCHAR, M. J. A.; ANJOS, J. R. N.; FERNANDES, F. D.; FERNANDES, C. D. Panicum maximum cv. Tanzânia nova hospedeira de Bipolaris maydis. Fitopatologia Brasileira, Brasília, v. 28, p. 385, 2003. Suplemento.

DALLAGNOL, L. J.; NAVARINI, L.; BALARDIN, R. S.; GOSENHEIMER, A.; MAFFINI, A. A. Dano das doenças foliares na cultura do arroz irrigado e eficiência de controle dos fungicidas. Revista Brasileira de Agrociências, Pelotas, v. 12, n. 3, p. 313-318, 2006.

GERDES, L.; WERNER, J. C.; COLOZZA, M. T.; POSSETI, R. A.; SCHMMAS, E. A. Avaliação de características de valor nutritivo das gramíneas forrageiras 
Marandu, Setária e Tanzânia nas estações do ano. Revista Brasileira de Zootecnia, Viçosa, MG, v. 29, n. 4, p. 955963. 2000.

GODOY, C. V.; CANTERI, M. G. Efeito da severidade de oídio e crestamento foliar de cercospora na produtividade da cultura da soja. Fitopatologia Brasileira, Brasília, v. 29, n. 5, p. 526-531, 2004.

GOODMAN, R. N.; KIRÁLI, Z.; WOOD, K. Z. The Biochemistry and physiology of plant disease. Columbia: Missouri Press, 1986. 433 p.

ISAWA, K. Deterioration in the chemical composition and nutritive value of forage crops by foliar diseases. III. Chemical composition and nutritive value of forage crops infected with Helminthosporium disease. Bulletin of the National Grassland Research Institute Japan. Nishinasuno - Tochigi, v. 2, n. 1, p. 41-56, 1983.

LAM, A. Effect of fungal pathogens on digestibility and chemical composition of Italian ryegrass (Lolium multiflorum) and tall fescue (Festuca arundinacea). Plant Pathology, Cambridge, v. 34, n. 2, p. 190-199, 1985.

LEITE, B.; PASCHOLATI, S. F. Hospedeiro: alterações fisiológicas induzidas por fitopatógenos. In: BERGAMIN FILHO, A.; KIMATI, H.; AMORIM, L. (Ed.). Manual de fitopatologia: princípios e conceitos. São Paulo: Ceres, 1995. v. 1, cap. 21, p. 393-413, 1995.

LENNÉ, J. M. Diseases of other pasture grasses. In: LENNÉ, J. M.; TRUTMANN, P. Diseases of tropical pasture plants. Wallingford, Oxon, UK: CBA International, 1994, $404 \mathrm{p}$.

LYTTLETON, J. W. Proteins and nucleic acids. In: BUTLER, G. W.; BAILEY, R. W. (Ed.). Chemistry and biochemistry of herbage. London: Academic Press. 1973. v. 1, p. 63-103.

MARTINEZ, A. S. Ocorrência de doenças e presença de fungos produtores de micotoxinas em gramíneas forrageiras em Marechal Cândido Rondon/PR. 2004.
Monografia (Graduação em Zootecnia) - Centro de Ciências Agrárias. Universidade Estadual do Oeste do Paraná, Marechal Cândido Rondon.

MUCHOVEJ, J. J.; MUCHOVEJ, R. M. C.; RIBEIRONESIO, M. L. Taxonomia de Drechslera, Bipolaris e Exserohilum. Fitopatologia Brasileira. Brasília, v. 13, n. 3, p. 211-223, 1988.

REGO, F. C. A.; CECATO, U.; DAMASCENO, J. C.; RIBAS, N. P.; SANTOS, G. T.; MOREIRA, F. B.; RODRIGUES, A. M. Valor nutritivo do capim - Tanzânia (Panicum maximum Jacq cv. Tanzânia-1) manejado em alturas de pastejo. Acta Scientiarum, Maringá, v. 25, n. 2, p. 363-370, 2003.

RUSSOMANNO, O. M. R. Fungos de importância veterinária (aspectos vegetais e manejo). Biológico, São Paulo, v. 60, n. 2, p. 25-32, 1998.

SANTOS, P. M. Controle da produção de haste no capim Tanzânia: um desafio. 2002. Tese (Doutorado em Agronomia) - Departamento de Zootecnia. Escola Superior de Agricultura "Luiz de Queiroz, Piracicaba.

SHANNER, G.; FINNEY, R. E. The effect of nitrogen fertilization on the expression of slow-mildewing resistance in Knox wheat. Phytopathology, v. 67, n. 8, p. 1051-1056, 1977.

SILVA, D. J. Análise de alimentos: métodos químicos e biológicos. Viçosa, MG: UFV, 1998, 165 p.

TEIXEIRA, A. C. B.; GOMIDE, J. A.; OLIVEIRA, J. A; ALEXANDRINO, E.; LANZA, D. C. F. Distribuição de fotoassimilados de folhas do topo e da base do CapimMombaça (Panicum maximum Jacq.) em dois estágios de desenvolvimento. Revista Brasileira de Zootecnia, Viçosa, MG, v. 34, n. 2, p. 479-488, 2005.

TEODORO, R. E.; AQUINO, T. P.; CHAGAS, L. A. C. Irrigação na produção de capim Panicum maximum cv. Tanzânia. Bioscience Journal, Uberlândia, v. 18, n. 1, p. 13-21, 2002. 